\title{
UJI DAYA HAMBAT EKSTRAK ETANOL DAUN SINGKONG (Manihot utilissima Pohl) YANG BERASAL DARI KABUPATEN PANGKAJENE SIDRAP TERHADAP PERTUMBUHAN BAKTERI Staphylococcus aureus
}

\author{
Andi Nurpati Panaungi \\ STIKES Nani Hasanuddin Makassar \\ Email : Andianti82@gmail.com
}

\begin{abstract}
ABSTRAK
Telah dilakukan penelitian uji daya hambat ekstrak etanol daun singkong (Manihot utilissima pohl) yang berasal dari kabupaten pinrang terhadap pertumbuhan bakteri Staphylococcus aureus. Tujuan dari penelitian untuk mengetahui daya hambat ekstrak etanol daun singkong (Manihot utilissima pohl) terhadap pertumbuhan bakteri Staphylococcus aureus. Proses ekstraksi dilakukan dengan metode maserasi dengan menggunakan pelarut etanol 70\%. Ekstrak yang diperoleh kemudian dibuat suspensi pada konsentrasi $20 \%$, $30 \%, 40 \%$, kontrol positif (eritromisin) dan kontrol negatif (aquadest) yang kemudian diujiakan daya hambatnya pada bakteri Staphylococcus aureus. Hasil yang diperoleh pada konsentrasi $20 \%$ adalah 11,33 mm, konsentrasi $30 \%$ adalah 12,66 mm, konsentrasi $40 \%$ adalah $15,33 \mathrm{~mm}$, sedangkan pada kontrol positif adalah $21 \mathrm{~mm}$ dan kontrol negatif tidak terlihat adanya zona hambatan.
\end{abstract}

Kata kunci : Ekstrak Daun Singkong, Staphylococcus Aureus

\section{PENDAHULUAN}

Indonesia yang terletak didaerah tropis memiliki keunikan dan kekayaan hayati yang sangat luar biasa. Tercatat tidak kurang dari 30.000 jenis tanaman obat yang tumbuh di indonesia walaupun yang sudah tercatat sebagai produk fitokimia (biasa diresepkan) baru terdapat sebanyak 5 produk dan obat herbal terstandar tercatat sebanyak 28 produk (Kuspradini, dkk, 2016).

Masyarakat Indonesia telah lama memanfaatkan tumbuhan obat sebagai upaya alternatif untuk penanggulangan masalah kesehatan, dimana penggunaannya dilakukan secara turun-temurun. Berkaitan dengan masalah kesehatan yang ada, hendaknya informasi yang diberikan kepada masyarakat harus benar dan disertai dengan data ilmiah yang berasal dari hasil penelitian tumbuhan yang berkhasiat sebagai obat (Rikomah, dkk,2017).

Salah satu tumbuhan obat yang digunakan secara turun-temurun yaitu tanaman daun singkong (Manihot utilissima Pohl). Kandungan yang terdapat dalam daun singkong yaitu air, fosfor, karbohidrat, kalsium, vitamin C, protein, lemak, vitamin B1, zat besi, flavonoid, saponin, tanin dan triterpenoid. Masyarakat mempercayai daun singkong memiliki berbagai manfaat untuk pengobatan penyakit. Masyarakat mempercayai daun singkong dapat mengobati rematik, asamurat, anemia, konstipasi, serta untuk meningkatkan daya tahan tubuh(Rikomah, dkk, 2017).

Telah dilakukan penelitian oleh Mutia dkk yang mengemukakan bahwa daun singkong (Manihot utilissima Pohl) memiliki kandungan flavonoid, saponin dan tanin yang digunakan sebagai anti bakteri. Berdasarkan uraian diatas maka akan dilakukan penelitian mengenai uji daya hambat ekstrak etanol daun singkong (Manihot utilissima Pohl)terhadap pertumbuhan bakteri Staphylococus aureus.

\section{METODE}

Lokasi, populasi, dan sampel penelitian

Penelitian ini adalah penelitian eksperimen untuk mengetahui daya hambat ekstrak etanol daun singkong (Manihot utilissima Pohl) terhadap bakteri Staphylococcus aureus. Penelitian dilakukan mulai bulan 07 Juli 2018 di laboratorium mikrobiologi Stikes Nani Hasanuddin Makassar. Populasi dalam penelitian ini yaitu tanaman singkong (Manihot utilissima Pohl) yang berasal dari Kabupaten Pangkajene sidrap. Sampel dalam penelitian ini adalah 200 gram daun singkong (Manihot utilissima Pohl) dengan menggunakan variasi konsentrasi.

\section{Pembuatan ekstrak}

Sebanyak 200 gram daun singkong (Manihot utilissima Pohl) yang telah dikeringkan dimaserasi dengan etanol $70 \%$ sebanyak 2,5 L selama 3x24 jam. Diaduk sesekali selanjutnya, residu maserasi yang telah dilarutkan sebanyak dua kali dengan etanol $70 \%$ dan hasil maserasi disatukan untuk dikumpulkan kemudian diuapkan dengan alat 
rotavavor untuk mendapatkan ekstrak etanol kental daun singkong (Manihot utilissima Pohl).

Ekstrak daun singkong 20\% dibuat dengan cara menimbang 2 gr ekstrak kemudian disuspensikan dalam aquadest steril hingga $10 \mathrm{ml}$, ekstrak daun singkong 30\% dibuat dengan cara menimbang 3 gr ekstrak kemudian disuspensikan dalam aquadest steril hingga $10 \mathrm{ml}$, ekstrak daun singkong $40 \%$ dibuat dengan cara menimbang 4 gr ekstrak kemudian disuspensikan dalam aquadest steril hingga $10 \mathrm{ml}$.

\section{Uji Daya Hambat}

Disiapkan medium Nutrient Agar/NA steril cair, didinginkan hingga suhu sekitar $45^{\circ} \mathrm{C}$ kemudian dituang secara aseptis kedalam cawan petri steril sebanyak $15 \mathrm{ml}$ dan dibiarkan memadat, ini sebagai lapisan dasar (based layer). Setelah itu $10 \mathrm{ml}$ medium NA dicampur dengan $1 \mathrm{ml}$ suspensi bakteri uji sebagai seed layer didalam tabung reaksi steril dan dituang diatas based layer. Paper disk 1-4 masing-masing direndam kedalam ekstrak daun singkong dengan konsentrasi $20 \% \mathrm{~b} / \mathrm{v}, 30 \% \mathrm{~b} / \mathrm{v}$, dan $40 \%$ b/v. Paper disk ke 5 direndam kedalam suspensi eritromisin sebagai kontrol positif, sedangkan paper disk ke 6 direndam kedalam aquadest steril sebagai control negatif.Setelah itu paper disk dimasukkan kedalam medium secara aseptis diatas permukaan medium yang setengah padat.Kemudian diinkubasi pada shu $37^{\circ} \mathrm{C}$ selama 1x24 jam.

\section{HASIL PENELITIAN}

Berdasarkan hasil penelitian pengukuran diameter zona hambat ekstrak etanol daun singkong (Manihot utilissima Pohl) terhadap Staphylococus aureus selama $1 \times 24$ jam diperoleh hasil penelitian sebagai berikut:

Tabel 1: Data Pengukuran Diameter Zona Hambatan (mm) Ekstrak Etanol Daun Singkong (Manihot utilissima Pohl)

\begin{tabular}{|c|c|c|c|c|c|}
\hline Replikasi & \multicolumn{5}{|c|}{ Diameter Zona Hambatan (mm) } \\
\hline & KN & KP & $20 \%$ & $30 \%$ & $40 \%$ \\
\hline 1 & 0 & 22 & 11 & 12 & 15 \\
\hline 2 & 0 & 20 & 11 & 12 & 15 \\
\hline 3 & 0 & 21 & 12 & 14 & 16 \\
\hline Total & 0 & 63 & 34 & 38 & 46 \\
\hline $\begin{array}{c}\text { Rata- } \\
\text { Rata }\end{array}$ & 0 & 21 & 11,33 & 12,66 & 15,33 \\
\hline
\end{tabular}

Keterangan :

$\mathrm{KN}=$ Kontol Negatif (Aquadest)

$\mathrm{KP}=$ Kontrol Positif (Eritromisin)

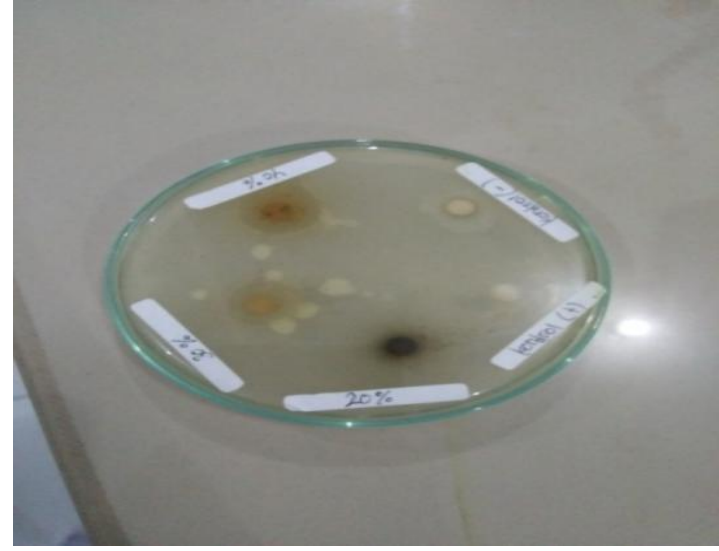

\section{PEMBAHASAN}

Penelitian ini bertujuan untuk mengetahui diameter zona hambatan dari ekstrak daun singkong (Manihot utilissima Pohl) terhadap pertumbuhan Staphylococus aureus. Metode yang digunakan pada ekstrak daun singkong (Manihot utilissima Pohl) yaitu metode maserasi karena salah satu jenis ekstraksi padat cair yang paling sederhana, pengerjaannya yang lebih mudah dan peralatan yang digunakan juga sederhana dan dapat menghindari rusaknya komponen senyawa akibat panas.

Penelitian dilakukan menggunakan cawan petri kemudian diletakkan lima peper disk dengan konsentrasi yang berbeda dan menghasilkan zona hambatan yang berbeda pula. Zona hambatan ditandai dengan adanya lingkaran transparan disekitar paper disk yang disebabkan oleh proses difusi ekstrak etanol dau singkong (Manihot utilissima Pohl) yang menghambat pertumbuhan Staphylococcus aureus.

Pada penelitian ini kontrol negatif yang digunakan yaitu aquades sekaligus juga merupakan larutan pengencer ekstrak daun singkong (Manihot utilissima Pohl) dan kontrol positif yang digunakan yaitu eritromisin karena merupakan salah satu antibiotik yang dapat menghambat bakteri gram positif.

Ekstrak etanol daun singkong (Manihot utilissima Pohl) yang digunakan yaitu konsentrasi $20 \%$, 30\%, dan $40 \%$ dengan menggunakan eritromisin sebagai kontrol positif dan aquadest sebagai kontrol negatif. Penelitian yang telah dilakukan menunjukkan hasil adanya daya hambatan yang transparan dan melingkar disekitar paper disk, sebagai tanda bahwa ekstrak etanol daun singkong (Manihot utilissima Pohl) dapat menghambat pertumbuhan bakteri Staphylococcus aureus.

Pengukuran daya hambat ekstrak etanol daun singkong terhadap Staphylococcus aureus dilakukan dengan menggunakan jangka sorong, dimana diperoleh diameter rata-rata pada konsentrasi $20 \%$ adalah $11,33 \mathrm{~mm}$, konsentrasi $30 \%$ adalah $12,66 \mathrm{~mm}$, konsentrasi $40 \%$ adalah 
15,33 mm, sedangkan pada kontrol positif adalah $21 \mathrm{~mm}$ dan kontrol negatif tidak terlihat adanya zona hambatan.

Pada diameter zona hambatan yang diperoleh sesuai hasil pengamatan, memperlihatkan bahwa konsentrasi $40 \%$ zona diameter hambatnya lebih besar dibandingkan dengan konsentrasi $20 \%$ dan $30 \%$ berdasarkan hasil pengamatan diperoleh hasil yang sesuai dengan teori bahwa semakin besar konsentrasi maka semakin besar diameter zona hambatan yang terbentuk.

Hasil analisis menggunakan metode Rancangan Acak Lengkap (RAL) menunjukkan bahwa semua konsentrasi dapat menghambat bakteri Staphylococcus aureus tapi masih dibawah eritromisin. Hal ini sesuai dengan penelitian yang dilakukan Mutia, dkk dimana menunjukkan ekstrak etanol daun singkong dapat menghambat bakteri Staphylococcus aureus.

\section{KESIMPULAN}

Berdasarkan hasil penelitian yang dilakukan maka dapat disimpulkan bahwa: Pada konsentrasi $20 \%$ diperoleh diameter rata-rata $11,33 \mathrm{~mm}$. Pada konsentrasi $30 \%$ diperoleh diameter rata-rata 12,66 mm. Pada konsentrasi $40 \%$ diperoleh diameter ratarata $15,33 \mathrm{~mm}$. Pada Kontrol positif diperoleh diameter rata-rata $21 \mathrm{~mm}$. Pada kontrol negatif tidak diperoleh diameter rata-rata.

\section{SARAN}

Berdasarkan penelitian yang dilakukan maka disarankan untuk dilakukan penelitian lebih lanjut tentang identifikasi kandungan kimia yang berkhasiat menghambat pertumbuhan bakteri.

\section{DAFTAR PUSTAKA}

Hanani Endang. 2014. Analisis Fitokimia. EGC, Jakarta.

Harti Agnes Sri. 2015. Mikrobiologi Kesehatan. ANDI OFFSET, Yogyakarta.

Hidayat, S., Napitupulu, R, M,.2015. Kitab Tumbuhan Obat. AgriFlo, Jakarta.

Iftita Faya Azjka. 2016. Uji Efektifitas Rendaman Daun Singkong (Manihot utilissima) Sebagai Insektisisda Terhadap Nyamuk Aedes aegypti Dengan Metode Elektrik Cair. Jurnal Kesehatan Masyarakat.Vol.4. No.2.

Kurniawati Evi. 2015. Daya Antibakteri Ekstrak Etanol Tunas Bambu Apus Terhadap Bakteri Eschericia coli dan Staphylococcus aureus Secara In Vitro.Universitas Airlangga, Surabaya. Vol.2, No. 2.

Kuspadini, H., pasedan, W, F., Kusuma, I, W., 2016.Aktivitas Antioksidan dan Antibakteri Ekstrak Daun Pometia pinnata. Universitas Mulawarman, Kalimantan Timur. Vol. 1 (1): 26-34.

Murwani, S., Qosimah, Dahliatul., Amri, I, A., 2017. Penyakit Bakterial Pada Ternak Hewan Besar dan Unggas. UB Press, Malang.

Mutia, C., Fitrianingsih, S,P., Choesrina, R., 2017. Uji Aktivitas Antibakteri Ekstrak Etanol Daun Singkong (Manihot esculenta Crantz) Terhadap Bakteri Escherichia coli danbakteri Staphylococus aureus Secara In Vitro. Universitas Islam Bandung. Vol.3, No. 1.

Radji, M., Biomed, M., 2013.Buku Ajar Mikrobiologi Panduan Mahasiswa Farmasi dan Kedokteran. EGC, Jakarta.

Rikomah, S, E., Elmitra., Yunita, D, G. 2017. Efek Ekstrak Etanol Daun Singkong (Manihot utilissima pohl) SEbagai Obat Alternatif Antiramatik Terhadap Rasa Sakit Pada Mencit.Akademi Farmasi Al-Fatah, Bengkulu.Vol 3 (2), 133-138.

Rosidah, I., Zainuddin., Mufidah, R., Bahua, H., Saprudin, M., 2017. Optimasi Kondisi Ekstrak Senyawa Total Fenolik Buah Labu Siam (Sechium edule (jacq.) sw.) Menggunakan Response Surface Methodology. Pusat Teknologi Farmasi dan Medika, Benten. 